\title{
Three new species of Bunchosia (Malpighiaceae): B. cuscana, B. hedraiophylla, and B. neillii
}

\author{
William R. Anderson and Christiane Anderson
}

University of Michigan Herbarium, 3600 Varsity Drive, Ann Arbor, MI 48108, USA; e-mail: chra@umich.edu

\begin{abstract}
Three new species of Bunchosia are described and illustrated. Bunchosia cuscana from Andean Peru bears two pseudoracemes per leaf axil, instead of the more common single inflorescence, and is compared with $B$. argentea with which it shares abaxially densely sericeous leaf blades and a 2-carpellate ovary. The 3-carpellate Mexican B. hedraiophylla has nearly sessile leaves and a paniculate inflorescence, an unusual character in Bunchosia that separates it from the B. macrophylla complex. Bunchosia neillii from Amazonian Ecuador is 3-carpellate and has glabrous leaves and petals with a glandular margin. A key is provided to separate B. neillii from similar species of western Amazonia and the Andes and of eastern Brazil.
\end{abstract}

Key Words: Malpighiaceae, Bunchosia, Ecuador, Mexico, Peru.

Bunchosia Kunth comprises ca. 75 species of shrubs and trees found from Mexico and the Caribbean to southeastern Brazil and adjacent Argentina. The genus is easily recognized by the epipetiolar stipules, lateral inflorescences with yellow flowers, large glands on the abaxial surface of leaf blades and on bracteoles, and fleshy fruits containing 2 or 3 pyrenes.

Two species from western South America, B. cuscana and B. neillii, and one from southern Mexico, B. hedraiophylla, are here newly described. The Peruvian B. cuscana is an Andean species distinctive in bearing two pseudoracemes per leaf axil and the broad, abaxially densely silvery or golden-sericeous leaves. Bunchosia neillii differs from other Amazonian species of Bunchosia with a 3-carpellate, glabrous ovary and glabrous leaves by its free styles, petals with a glandular margin, and the distally indented claw of the posterior petal. Most unusual is the Mexican $B$. hedraiophylla, which has a paniculate inflorescence, instead of the usual simple (or occasionally ternate) pseudoraceme, and nearly sessile leaves.

The only comprehensive treatment of Bunchosia since that of Jussieu (1843) in his monograph of the Malpighiaceae is the account by Niedenzu for Das Pflanzenreich (1928). Since then numerous new species have been described, but the genus has received detailed attention only in floristic accounts (e.g., Cuatrecasas 1958; Anderson 1981, 1988, 1999, 2001a, b, 2007;
Cuatrecasas \& Croat 1981; González G., 2010). The late William R. Anderson had intended to publish a monograph of Bunchosia; the three novelties proposed here are based on his notes and are to be attributed to him.

Bunchosia cuscana W. R. Anderson, sp. nov. Type. Peru. Cusco: Urubamba, Dist. Machu Picchu, San Miguel, 1309'S, 72³0'W, 1679 m, 20 Apr 2003 (fl), L. Valenzuela, G. Calatayud \& I. Huamantupa 1890 (holotype: $\mathrm{MICH}$; isotype: $\mathrm{MO}$ ).

(Fig. 1)

Similar to Bunchosia argentea but differs in its broadly elliptical to suborbicular, apically apiculate to shortacuminate leaf blades, two inflorescences per axil, and a glabrous ovary and fruit.

Shrub or small tree 6-25 m; stems sparsely sericeous but eventually glabrous. Blade of larger leaves $10-20 \times 7.5-17 \mathrm{~cm}$, broadly elliptical to suborbicular, apex apiculate to short-acuminate, base acute, margin flat, adaxially initially sparsely sericeous but soon glabrate to glabrous, abaxially very densely sericeous, the epidermis obscured, bearing 1 large gland abaxially on each side near the base and 0-2 additional large glands on each side up to $25 \mathrm{~mm}$ above the base and near the margin, also with none to many scattered smaller inframarginal glands to the apex; petiole 6$13 \mathrm{~mm}$ long, sericeous, eglandular; stipules 1$2 \mathrm{~mm}$ long. Inflorescence a simple pseudoraceme 

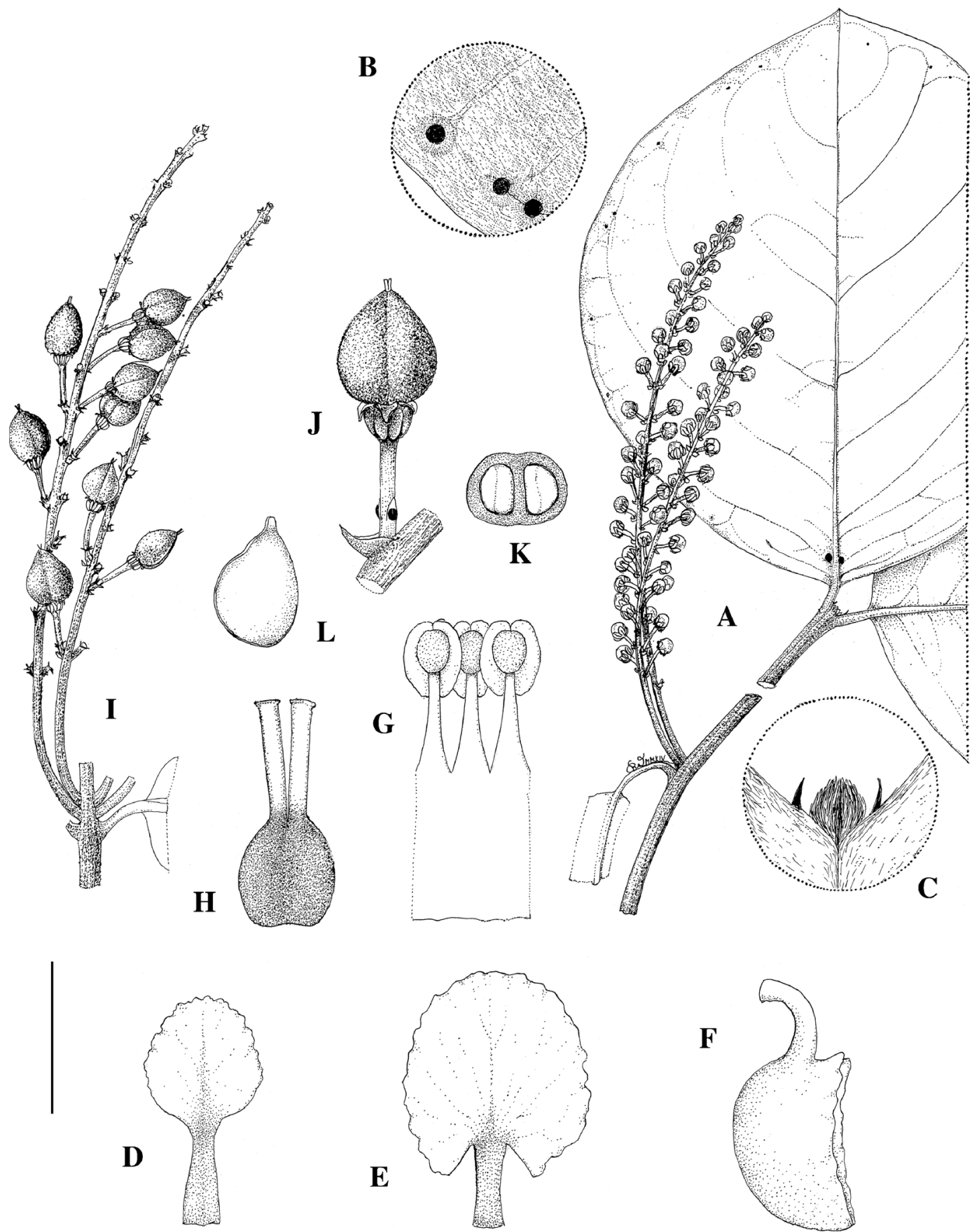

Fig. 1. Bunchosia cuscana. A. Branch with paired inflorescences in bud. B. Detail of abaxial leaf surface with marginal leaf glands. C. Detail of branch apex, showing stipules. D. Posterior petal. E. Posterior-lateral petal. F. Anterior-lateral petal. G. Portion of androecium. H. Gynoecium. I. Portion of stem with paired infructescences. J. Fruit borne on subsessile pedicel, subtended by bracteoles and bract. K. Cross-section of fruit. L. Embryo. Scale bar equivalents: A, I, 4 cm; B, 8 mm; C-F, 4 mm; G, H, 2 mm; J, K, $2 \mathrm{~cm}$; L, $1.3 \mathrm{~cm}$. (A, D-H from the holotype; B, C from Valenzuela et al. 5406, MICH; I-L from Calatayud \& Suclli 1856, $\mathrm{MICH}$. 
borne 2 per axil, $8-18 \mathrm{~cm}$ long and containing 15-24+ flowers, these mostly decussate distally but often alternate proximally; bracts $1.5-$ $2 \mathrm{~mm}$ long, triangular, apex acute, margin eciliate or with a few hairs; peduncles 0 $1 \mathrm{~mm}$ long ( $-3 \mathrm{~mm}$ in fruit); bracteoles 1$1.3 \mathrm{~mm}$ long, margin eciliate or with a few hairs, one of the pair or both bearing a large abaxial gland $0.6-1(-1.5) \mathrm{mm}$ in diameter; pedicels $4-7 \mathrm{~mm}$ long in flower $(-11 \mathrm{~mm}$ in fruit); axes, pedicels, and abaxial surface of bracts and bracteoles sparsely and scattered sericeous. Sepals 1-1.5 mm long beyond glands, apex acute, margin ciliate, abaxially glabrous, all biglandular, glands ca. $2.5 \mathrm{~mm}$ long, the distal ca. 1/4 free and spreading to reflexed. Petals yellow, glabrous, lateral petals reflexed, the margin wavy and suberose; anteriorlateral petals with the claw ca. $2.5 \times$ ca. $0.5 \mathrm{~mm}$, limb ca. $5 \mathrm{~mm}$ in diameter, concave; posteriorlateral petals with the claw ca. $2.5 \times$ ca. $0.5 \mathrm{~mm}$, limb ca. $4.5 \mathrm{~mm}$ in diameter, slightly concave; posterior petal ("flag") erect, the claw ca. $3 \times$ ca. 1 $\mathrm{mm}, \operatorname{limb}$ ca. $3.5 \times$ ca. $3 \mathrm{~mm}$, suborbicular, flat, margin erose-dentate. Filaments ca. $2.1-2.2 \mathrm{~mm}$ long, glabrous, 1/2-2/3 connate; anthers ca. $1 \mathrm{~mm}$ long. Gynoecium 2-carpellate, glabrous; ovary ca. $1.5 \mathrm{~mm}$ high, ovoid; styles 2, free, ca. $1.5 \mathrm{~mm}$ long, glabrous. Fruit reddish brown at maturity, (8-) 10-15 × (7-) 8.5-13 mm, ovoid, 2-lobed, glabrous, verruculose; embryo ca. $10 \times$ ca. 6.5 $\mathrm{mm}$, ovoid.

Distribution and habitat.-Peru; in primary and secondary forest, 1945-2950 m.

Phenology.-Collected with flowers in March and April and in fruit in August and September.

Etymology.-The species is named for the Departamento del Cusco, the source of all the collections.

Additional specimens examined. PERU. Cusco: Urubamba, Dist. Machu Picchu, Aguas Calientes, $13^{\circ} 08^{\prime} \mathrm{S}$, 72³2’W, 1945 m, 29 Aug 2003 (fr), Calatayud \& Suclli 1856 (MICH, MO); La Convención, Dist. Santa Ana, Tunquimayo, $12^{\circ} 54^{\prime} 31^{\prime \prime} \mathrm{S}, 72^{\circ} 48^{\prime} 45^{\prime \prime} \mathrm{W}, 2110 \mathrm{~m}, 20 \mathrm{Sep}$ 2004 (y fr), Calatayud et al. 2773 (MICH, MO); La Convención, Dist. Santa Teresa, Yerbabuenayoc, $13^{\circ} 07^{\prime} 35^{\prime \prime S}$, 72³6'52"W, 2420 m, 22 Mar 2005 (fl buds), Huamantupa \& Huamantupa 4290 (MICH, MO); La Convención, Dist. Santa Teresa, Yerbabuenayoc, $13^{\circ} 04^{\prime} \mathrm{S}, 7^{\circ} 22^{\prime} \mathrm{W}, 2420 \mathrm{~m}$, 16 Sep 2005 (y fr), Huamantupa et al. 6577 (MICH, MO); La Convención, Dist. Santa Teresa, Yanatile, $13^{\circ} 05^{\prime} \mathrm{S}, 72^{\circ} 23^{\prime} \mathrm{W}$, 2950 m, 16 Apr 2005 (fl), Valenzuela et al. 5406 (MICH, MO).

At first glance Bunchosia cuscana may be confused with the widespread B. argentea (Jacq.)
DC., with which it shares a 2-carpellate ovary and a silvery to golden-sericeous pubescence on the abaxial laminar surface, which is so dense as to hide the epidermis. Bunchosia cuscana is distinctive in bearing nearly always two inflorescences per leaf axil; the pseudoracemes of $B$. argentea are borne singly. In $B$. cuscana the ovary is glabrous, even at the youngest stage, as are the fruits, which have a verruculose surface when dried. The ovary of $B$. argentea is densely sericeous, as is the fruit, which may become eventually glabrescent. In both species the fruit is ovoid, but that of B. cuscana narrowly so and distinctly bilobed. The two species also differ in their leaves. The leaf blades of B. cuscana are very broadly elliptical to suborbicular and apically apiculate to short-acuminate; the stipules are 1-2 $\mathrm{mm}$ long. Bunchosia argentea has elliptical leaf blades that are abruptly acuminate at the apex, and its stipules are only ca. $0.5 \mathrm{~mm}$ long.

Bunchosia hedraiophylla W. R. Anderson, sp. nov. Type. Mexico. Oaxaca: Distr. Pochutla, Mpio. San Miguel del Puerto, Cafetal "Arroyo Arena," 1558'33.6"N, 9606'5.1"W, $820 \mathrm{~m}$, 12 Dec 2003 (fl), A. Nava Z. 275 (holotype: $\mathrm{MICH})$.

(Fig. 2)

Similar to Bunchosia macrophylla but differs in its subsessile leaves, paniculate inflorescence, and glabrous ovary with the styles completely connate.

Shrub or small tree 1.5-4 m tall; stems densely velutinous with short Y-shaped hairs in first year, glabrate in second year. Blade of larger leaves 15$24 \times 9-14.5 \mathrm{~cm}$, broadly elliptical or somewhat ovate or obovate, apex obtuse or acute, base shallowly cordate, margin, flat, adaxially initially short-velutinous but soon glabrate except persistently hairy on midrib, especially proximally, abaxially very densely and persistently velutinous or tomentose with T-shaped hairs, usually bearing a row of 10-13 glands set in from each abaxial margin; petiole 2-4 mm long, densely and persistently velutinous, eglandular; stipules (when evident) ca. $2 \mathrm{~mm}$ long. Inflorescence a terminal or axillary panicle, the individual branches $4.5-$ $9.5 \mathrm{~cm}$ long and containing 12-24 flowers, these mostly decussate; bracts $1.5-2 \mathrm{~mm}$ long, triangular, apex acute, margin ciliate; peduncles absent or rudimentary; bracteoles $1-1.3 \mathrm{~mm}$ long, margin ciliate, one of the pair bearing a large abaxial gland $1-1.5 \mathrm{~mm}$ in diameter; pedicels $3.5-$ 


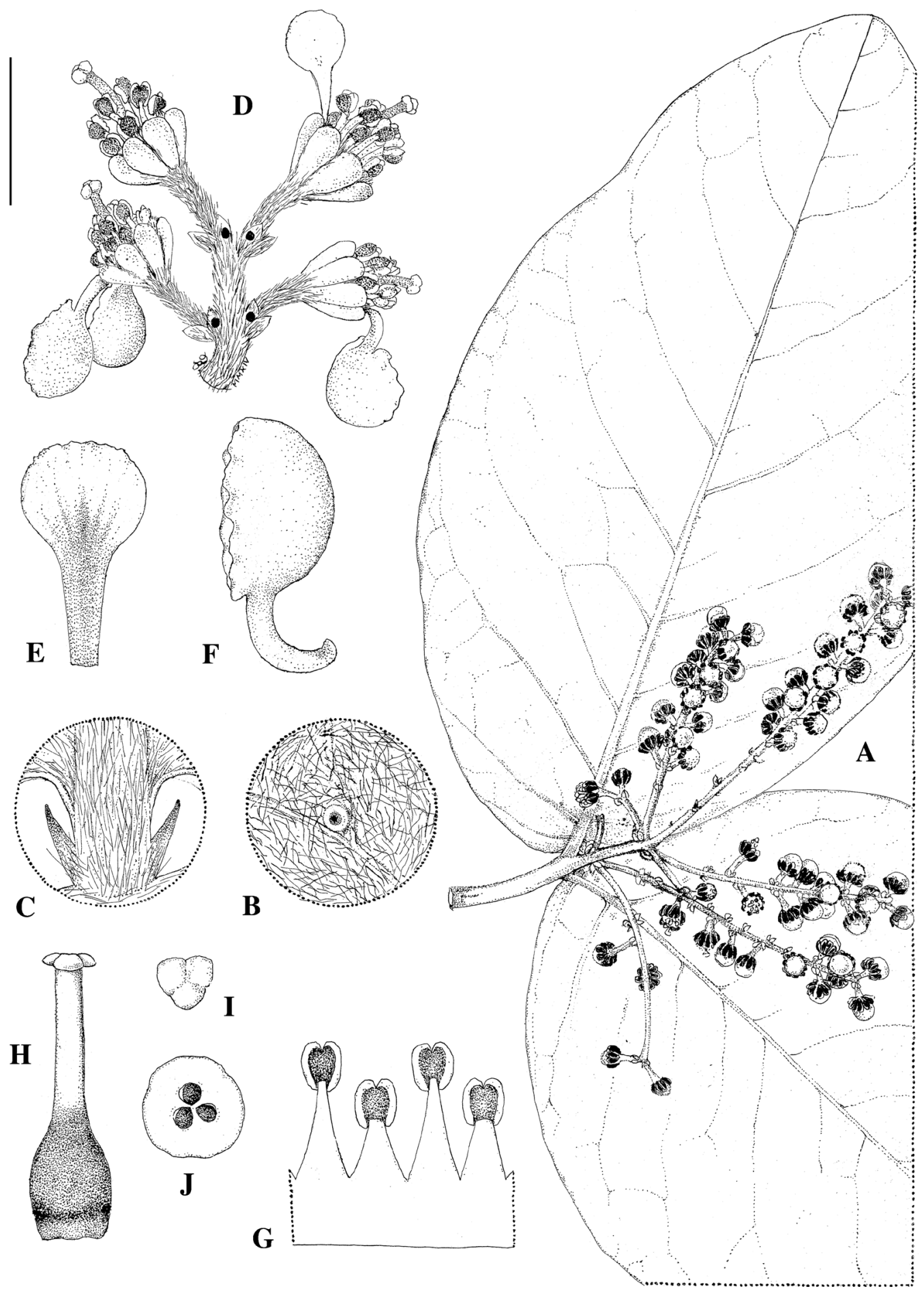

Fig. 2. Bunchosia hedraiophylla. A. Branch with inflorescence in bud. B. Detail of abaxial leaf surface with leaf gland. C. Detail of rudimentary petiole and pair of stipules. D. Apical portion of inflorescence. E. Posterior petal. F. Lateral petal. G. Portion of androecium. H. Gynoecium. I. Stigma. J. Cross-section of ovary. Scale bar equivalents: A, 4 cm; B, C, E, F, 4 mm; D, 8 mm; GI, $2.7 \mathrm{~mm}$; J, 2 mm. (A, B, D-I from the holotype; C from Morton \& Makrinius 2705, US.) 
$6 \mathrm{~mm}$ long; axes, pedicels, and abaxial surface of bracts and bracteoles densely covered with a mixture of $\mathrm{Y}$ - and T-shaped hairs, the epidermis obscured. Sepals $1-1.5(-2) \mathrm{mm}$ long beyond glands, apex rounded, margin ciliate, abaxially with a mixture of $\mathrm{Y}$ - and T-shaped hairs, all biglandular, glands $3-3.5 \mathrm{~mm}$ long, the distal ca. 1/3 free and spreading to reflexed. Petals yellow, glabrous; lateral petals reflexed, the limb orbicular and concave, margin wavy and suberose; anterior-lateral petals with the claw ca. $3 \times 0.5 \mathrm{~mm}$, limb ca. $6 \mathrm{~mm}$ in diameter, posterior-lateral petals with the claw ca. $2.5 \times$ ca. $0.5 \mathrm{~mm}$, limb ca. $5 \mathrm{~mm}$ in diameter, posterior petal ("flag") erect, with the claw ca. $3 \times 1 \mathrm{~mm}$, limb ca. $3.5 \times 4 \mathrm{~mm}$, oblate, flat, margin distally erose. Filaments ca. $2.5 \mathrm{~mm}$ long opposite sepals, ca. $2 \mathrm{~mm}$ long opposite petals, glabrous, ca. 1/3-1/2 connate; anthers ca. $1 \mathrm{~mm}$ long. Gynoecium 3-carpellate, glabrous; ovary ca. $1.7 \mathrm{~mm}$ high, narrowly ovoid; style $3.2-3.5 \mathrm{~mm}$ long, seemingly 1 but composed of 3 completely connate and the stigma 3-lobed. Mature fruit not seen; immature fruit spherical, glabrous, "orange" (fide label of Morton \& Makrinius 2705).

Distribution and habitat.-Mexico: Oaxaca; lowland to mid-elevation deciduous or subperennial forest; 400-1159 m.

Phenology.-Collected with flowers in September and December and with young fruits in April.

Etymology.-The specific epithet of this species comes from the Greek words for sessile (hedraios) and leaf (phyllon). It refers to the fact that the large leaf is borne on a very short, almost absent petiole.

Additional specimens examined. MEXICO. Oaxaca: Vic. of Cafetal Concordia [near Pochutla], 400-650 m, 1-15 Apr 1933 (fr), Morton \& Makrinius 2705 (US); Distr. Yautepec, Mpio. San Bartolo Yautepec, Tejón, 16²2'55.1"N, 960'14.5"W, 1159 m, 30 Sep 2010 (fl), D. López Pascual 402 (MICH); Distr. Pochutla, Mpio. San Miguel del Puerto, Santa Ma. Xadani a Piedra de Agua, 1557'11.2"N, 9606’23.6"W, 1130 m, 21 Dec 2001 (fl), J. Pascual 252 (MICH).

Bunchosia hedraiophylla is readily recognized by its large, nearly sessile leaf blades and the highly unusual paniculate inflorescences. A dense pubescence composed of Y- and T-shaped hairs covers all vegetative parts, except second-year and older stems and branches. The ovary is glabrous and 3-carpellate; the three styles are fused into one structure terminating in a 3-lobed stigma.
The velutinous vesture, especially on leaf blades, may lead to confusion with B. macrophylla Rose s.l., which differs in its petiolate leaves and flowers arranged in pseudoracemes (the usual condition in the genus). Also, in B. macrophylla the ovary is densely sericeous, and, although the three styles are also completely connate, the stigmas are free.

Bunchosia hedraiophylla is known from only three collections in bud or early flower, and one (Morton \& Makrinius 2705) with three immature fruits in a packet. The fruits are spherical (somewhat flattened by pressing) but uneven, possibly owing to not having all three locules containing developing seeds.

Bunchosia neillii W. R. Anderson, sp. nov. Type. Ecuador. Napo: Orellana, Yasuní National Park, Maxus Petroleum pipeline road, under construction, $\mathrm{Km}$ 18-26, 00³5'S, 76³0’W, 230 m, 11 Dec 1993 (fl), D. Neill, G. Tipaz \& A. Dik 10275 (holotype: $\mathrm{MO}$; isotype: $\mathrm{MICH}$ ).

Similar to Bunchosia bonplandiana, B. cauliflora, and $B$. systyla in its glabrous leaf blades and glabrous, 3carpellate ovary, but differs from B. cauliflora and B. systyla in its distinct styles, and from $B$. bonplandiana in its lateral petals with a glandular margin.

Small tree $3 \mathrm{~m}$; stems glabrous. Blade of larger leaves $8.5-18 \mathrm{~cm} \times 4-7 \mathrm{~cm}$, elliptical or narrowly so, apex acuminate (apiculate in smaller leaf blades), base acute, margin flat, adaxially and abaxially initially very sparsely sericeous but soon glabrous, bearing 1 large gland abaxially on each side near the base; petiole (5-) 6-9.5 mm long, sparsely sericeous to glabrous, eglandular; stipules $1-1.5 \mathrm{~mm}$ long. Inflorescence a simple pseudoraceme, 1 per axil, 6.5-9 cm long and containing 15-32 flowers, these mostly decussate; bracts 2$2.5 \mathrm{~mm}$ long, linear-triangular, apex acute; peduncles 2.5-3.5 mm long; bracteoles ca. $1 \mathrm{~mm}$ long, one of the pair bearing a large abaxial gland $0.7-1 \mathrm{~mm}$ in diameter; pedicels 5$7.5 \mathrm{~mm}$ long; axes, peduncles, pedicels, and abaxial surface of bracts and bracteoles sparsely and scattered sericeous, bracts and bracteoles ciliate, especially distally. Sepals 1$1.5 \mathrm{~mm}$ long beyond glands, apex acute, margin ciliate, abaxially glabrous, all biglandular, glands ca. $2.5 \mathrm{~mm}$ long, the distal ca. 1/4 free and spreading to reflexed. Petals yellow, glabrous, margin of limb glandular-digitate- 


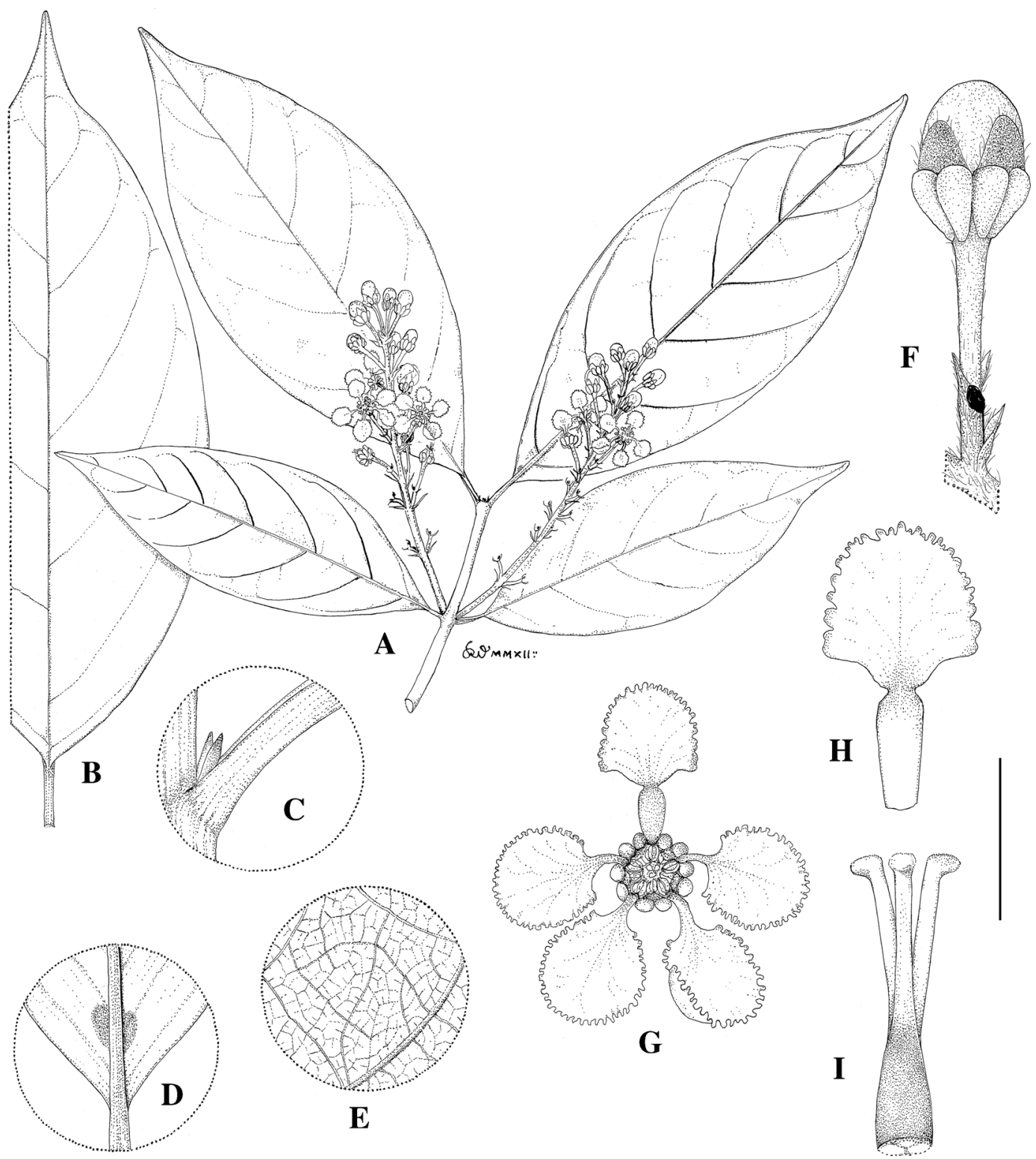

Fig. 3. Bunchosia neillii. A. Flowering branch. B. Large leaf, adaxial view. C. Base of petiole bearing stipules. D. Base of lamina, abaxial view, showing paired glands. E. Detail showing leaf venation, abaxial view. F. Flower bud. G. Flower, posterior petal uppermost. H. Posterior petal. I. Gynoecium. Scale bar equivalents: A, B, 4 cm; C, 4 mm; D, 8 mm; E, F, 4 mm; G, 8 mm; H, $5 \mathrm{~mm}$; I, $2.7 \mathrm{~mm}$. (Drawn from the holotype.)

fimbriate; lateral petals reflexed, the limb orbicular; anterior-lateral petals with the claw ca. $2.5 \times$ ca. $0.5 \mathrm{~mm}$, limb ca. $6 \mathrm{~mm}$ in diameter, concave; posterior-lateral petals with the claw ca. $2.5 \times 0.5 \mathrm{~mm}$, limb ca. $5 \mathrm{~mm}$ in diameter, slightly concave; posterior petal ("flag") erect, the claw ca. $3 \times 1 \mathrm{~mm}$, indented at apex, limb ca. $4 \mathrm{~mm}$ in diameter, suborbicular and tapered toward the base, flat. Filaments ca. $3 \mathrm{~mm}$ long, glabrous, 1/2-2/3 connate; anthers ca. $1.3 \mathrm{~mm}$ long. Gynoecium 3-carpellate, glabrous; ovary ca. $2 \mathrm{~mm}$ high, subcylindrical; styles 3, free, ca. $2.5 \mathrm{~mm}$ long, glabrous. Fruit unknown. 
Distribution and habitat.-Ecuador; primary moist tropical forests, 230-320 m.

Phenology.-Collected with flowers in December and January.

Etymology.-The species is named for David Alan Neill (b. 1953), student of the flora of Ecuador, who collected the type.

Bunchosia neillii has long, open, manyflowered inflorescences. All petals have a long claw and a limb with a glandular-dentate margin. The posterior ("flag") petal is distinctive in its apically indented claw and basally tapered limb. The glabrous, 3-carpellate gynoecium terminates in entirely distinct styles. The leaf blades are glabrous at maturity and bear only one large gland abaxially on each side near the base, but lack marginal glands.

Bunchosia neillii may be separated with the following key from other species of western Amazonia and the Andes [B. bonplandiana Adr. Juss., B. cauliflora W. R. Anderson, B. systyla (Nied.) Dobson] and of eastern Brazil (B. macilenta Dobson, B. maritima (Vell.) J. F. Macbr., B. pernambucana W. R. Anderson) with a glabrous, 3-carpellate ovary, glabrous or glabrate mature leaves, and inflorescences not immediately subtended by vegetative leaves. One collection of $B$. pseudonitida Cuatrec. is known from Ecuador (Thomas \& Ríos 6734, Los Ríos, Pedro Franco Davila Biol. Station, Jauneche); this species has connate styles.

1. Styles completely or $1 / 2$ connate.

2. Inflorescences borne on leafless stems at least one year old...B. cauliflora

2. Inflorescences born axillary to the leaves of current year's growth.

3. Inflorescence with 14-24-flowers, axis appressed-pilose...B. systyla

3. Inflorescence with 6-10 flowers, axis loosely sericeous to glabrate...B. pernambucana

1. Styles distinct (at most connate at base only).

4. Margin of lateral petals eglandular B. bonplandiana 4. Margin of all petals glandular.
5. Inflorescences with 4-8 flowers B. macilenta

5. Inflorescences with 15-32 flowers.

6. Leaf blades with $4-8$ abaxial glands near the midvein, or on or near the lateral veins B. maritima

6. Leaf blades with 2 abaxial glands near the base B. neillii

\section{Acknowledgments}

Karin Douthit drew the handsome illustrations. The curators of MICH and MO kindly provided access to their collections. I thank Tom Daniel and Scott Mori for their helpful reviews. This study was supported in part by a grant from the National Science Foundation to the University of Michigan (DEB-0543909).

\section{Literature Cited}

Anderson, W. R. 1981. Bunchosia. In: The botany of the Guayana Highland-Part XI. Memoirs of the New York Botanical Garden 32: 274-280.

-1988. Bunchosia. In: R. A. Howard (ed.), Flora of the Lesser Antilles, 4: 598-603. Arnold Arboretum, Harvard University, Jamaica Plain, Mass.

. 1999. Bunchosia. In: P. M. Jørgensen \& S. León-

Yánez (eds.), Catalogue of the Vascular Plants of Ecuador, Monographs in Systematic Botany from the Missouri Botanical Garden 75: 544-545.

. 2001a. Bunchosia. In: P. E. Berry, K. Yatskievych \& B. K. Holst (eds.), Flora of the Venezuelan Guayana, 6: 100-103. Missouri Botanical Garden Press, St. Louis. . 2001b. Bunchosia. In: W. D. Stevens, C. Ulloa Ulloa, A. Pool \& O. M. Montiel (eds.), Flora de Nicaragua, Angiospermas: Fabaceae-Oxalidaceae. Monographs in Systematic Botany from the Missouri Botanical Garden 85(2): 1261-1265.

. 2007. Bunchosia. In: B. E. Hammel, M. H. Grayum, C. Herrera \& N. Zamora (eds.), Manual de Plantas de Costa Rica, vol. 6, Monographs in Systematic Botany from the Missouri Botanical Garden 111: 263-272.

Cuatrecasas, J. 1958. Bunchosia. In: Prima Flora Colombiana. Malpighiaceae. Webbia 13: 565-588. \& T. B. Croat. 1981 [“1980"]. Bunchosia. In: R. E. Woodson, Jr. \& R. W. Schery (eds.), Flora of Panama-Part VI, Annals of the Missouri Botanical Garden 67: 861-871.

González Gutiérrez, P. A. 2010. A revision of Cuban Bunchosia (Malpighiaceae), with description of a new subspecies from Hispaniola. Willdenowia 40: 55-61.

Jussieu, Adr. de. 1843. Bunchosia. In: Monographie de la famille des Malpighiacées. Archives du Muséum d'Histoire Naturelle (Paris) 3: 330-342.

Niedenzu, F. 1928. Bunchosia. In: A. Engler (ed.), Das Pflanzenreich, 141 (Heft 94): 642-674. Wilhelm Engelmann, Leipzig. 